\title{
Allelopathy of Aromatic Species on the Germination of Cereus jamacaru DC. subsp. jamacaru (Cactaceae)
}

\author{
José Weverton A. Bezerra ${ }^{1,2}$, Marcos Aurélio F. dos $\operatorname{Santos}^{1}$, Marcos V. Meiado ${ }^{3}$, Karina V. Linhares ${ }^{1}$, \\ Aline A. Boligon ${ }^{4}$, Cicero dos S. Leandro ${ }^{1}$, Maria Daniele P. Rodrigues ${ }^{1}$, Ana Karolina F. Silva ${ }^{1}$, \\ Danúbio L. da Silva ${ }^{1}$, Janete de S. Bezerra ${ }^{1}$, Viviane B. da Silva ${ }^{1}$ \& Maria Arlene P. da Silva ${ }^{1}$ \\ ${ }^{1}$ Regional University of Cariri, Crato, CE, Brazil \\ ${ }^{2}$ Federal University of Pernambuco, Recife, PE, Brazil \\ ${ }^{3}$ Federal University of Sergipe, Professor Alberto Carvalho Campus, Itabaiana, SE, Brazil \\ ${ }^{4}$ Federal University of Santa Maria, Santa Maria, RS, Brazil \\ Correspondence: José Weverton A. Bezerra, Federal University of Pernambuco, Recife, PE, CEP: 50670-901, \\ Brazil. Tel: 55-889-8144-7371. E-mail: weverton.almeida@urca.br
}

Received: July 20, $2018 \quad$ Accepted: August 23, $2018 \quad$ Online Published: October 15, 2018

doi:10.5539/jas.v10n11p337 URL: https://doi.org/10.5539/jas.v10n11p337

\begin{abstract}
Cereus jamacaru DC subsp. jamacaru, has been suffering from severe anthropic pressure, in addition, when their seeds are dispersed, some end up not germinating due to the action of allelochemicals. Therefore, the present study was to evaluate the allelopathic effect of the essential oil (EO) from four species over C. jamacaru germination, as well as to identify their constituents. Four plants were selected for EO extraction (Mesospherum suaveolens (L.) Kuntze, Lantana montevidensis (Spreng.) Briq., Lantana camara L., and Tarenaya spinosa (Jacq.) Raf.) and the chemical analysis was performed by GC-MS. In order to evaluate the allelopathic activity of the EO's, the C. jamacaru seeds were treated with the EO's. The results showed that the EO's presented heterogeneity in their composition, with M. suaveolens presenting the highest number of constituents (44), followed by L. camara (26), T. spinosa (23) and L. montevidensis (22). All the oils negatively affected the $C$. jamacaru germination percentage in a concentration-dependent manner. Regarding the GVI, the M. suaveolens, L. montevidensis and L. camara OEs significantly decreased this index at all analyzed concentrations. Based on the results obtained, it is suggested that $C$. jamacaru should not be sown close to the aforementioned aromatic species in reforestation programs.
\end{abstract}

Keywords: allelochemicals, cactus, essential oil, Mandacaru

\section{Introduction}

The Cactaceae family is native to the Americas where a high species richness occurs (Judd, Campbell, Kellogg, Stevens, \& Donoghue, 2009). This taxon is very important in the maintenance of ecosystems, as in the case of the Caatinga, a Dry Tropical Forest located in the Northeastern region of Brazil, which given the availability of various resources (fruits, nectar, pollen and water) from the local fauna, directly participates in the food chain (Cavalcante, Teles, \& Machado, 2013; Gomes, Meiado, Quirino, \& Machado, 2016). Cereus jamacaru DC. subsp. jamacaru (Cactaceae) is an endemic species from Brazil known as "mandacaru" (Cavalcante et al., 2013; Menezes, Taylor, \& Loiola, 2014) and is a pioneer in the colonization of arid and inhospitable environments, especially outcrops. Birds indulged in their fruits, thus being the main animals responsible for the dispersion of its seeds through endozoochory (Gomes, Quirino, \& Araujo, 2014).

Despite its importance, this is a species threatened by intense anthropization of its natural environment and by the fact that, when its seeds are released into the environment, some are unable to germinate due to several factors (Meiado, Albuquerque, Rocha, Rojas-Aréchiga, \& Leal, 2010). One of these factors is the allelopathic action caused by secondary compounds, allelochemicals, produced by surrounding plants. These metabolites belong to the phenolic compounds, nitrogen compounds and terpenes groups (Gachon, Langlois-Meurinne, \& Saindrenan, 2005). Within the terpene group, volatile terpenes, also referred to as essential oils, may act through different mechanisms of action against seeds in order to impair water assimilation, nutrient uptake, protein synthesis and germinative biochemical processes (Oliveira Junior, Constantin, \& Inoue, 2011). 
Given the absence of $C$. jamacaru subsp. jamacaru together with aromatic plants, we hypothesized that some plant species may have an allelopathic effect on the germination and/or development of this species. Within the aromatic plants that occur in the Caatinga, some have a wide distribution as well as a high population density, such as Mesospherum suaveolens (L.) Kuntze (Lamiaceae), Lantana montevidensis (Spreng.) Briq. (Verbenaceae), Lantana camara L. (Verbenaceae), and Tarenaya spinosa (Jacq.) Raf (Cleomaceae). These species, during the drought periods lose their leaves, the site of essential oil synthesis, and therefore, the soil where they fall will contain several allelochemicals (Li, Wang, Ruan, Pan, \& Jiang, 2010). In the study by Sharma, Batish, Singh, Jaryan and Kohli (1995), it has been shown that Mesosphaerum suaveolens adversely impacts the number of species, diversity, richness and plant uniformity, so that infestation of this plant may compromise the succession of other plants in the community.

Considering the aspects related to this research, the objective of this study was to evaluate the allelopathic effect of the essential oil (EO) from four Caatinga species on C. jamacaru subsp. jamacaru germination, as well as to identify the chemical compounds present in these oils, in order to suggest potential actions to increase the efficiency of restoration strategies for environments in which the $C$. jamacaru subsp. jamacaru species is present.

\section{Materials and Methods}

\subsection{Botanic Material Collection}

To obtain the seeds, mature fruits were collected from 15 C. jamacaru subsp. jamacaru specimens in May 2016, from the Quixelô City - CE $\left(06^{\circ} 24^{\prime} 85.9^{\prime \prime} \mathrm{S}, 39^{\circ} 27^{\prime} 87.3^{\prime \prime} \mathrm{W}\right)$. On this occasion, plant materials with reproductive parts which were pressed, identified and deposited in the Caririense Dárdano de Andrade-Lima Herbarium (HCDAL) of the Regional University of Cariri (URCA) were also collected and stored under the record number 12.513 .

M. suaveolens (HCDAL 12.104), L. montevidensis (HCDAL 12.377), L. camara (HCDAL 12,609) and T. spinosa (HCDAL 12,625) samples were also collected from the same city in areas where $C$ jamacaru subsp. jamacaru specimens were also present. Leaves for essential oil extraction were collected in January 2017, at 09:00 $\pm 30 \mathrm{hrs}$, and left to dry in the shade.

\subsection{Essential Oil Extraction}

Essential oil (EO) extraction was carried out in a hydrodistillation system, as proposed by Matos (2009), with modifications. For this, the donor species dry leaves were ground to increase the contact surface and obtain a higher essential oil (EO) yield. In the hydrodistillation system, $200 \mathrm{~g}$ of the dried leaves from each donor species together with 4 liters of distilled water were conditioned and the mixture was boiled for 2 hours. The oil was collected with a glass pipette and stored in a refrigerator at $-10{ }^{\circ} \mathrm{C}$ until the chemical analyzes and the allelopathy tests were performed.

\subsection{Chemical Composition Analysis}

Essential oil chemical composition analysis was carried out by Gas Chromatography coupled to Mass Spectrometry (CG/MS), using a Shimidzu QP2010 Series equipment to identify the constituents, possibly responsible for the allelopathic action. The Rtx-5MS type capillary column, measuring $30 \mathrm{~m}$ in length by 0.25 $\mathrm{mm}$ in diameter and $0.25 \mu \mathrm{m}$ in film thickness was used. Helium gas at a rate of $1.5 \mathrm{~mL} / \mathrm{min}$ was used as a carrier. The injector temperature was $250{ }^{\circ} \mathrm{C}$ and the detector temperature was $290{ }^{\circ} \mathrm{C}$. The essential oil was diluted in a 1:200 proportion in chloroform, with $1 \mu \mathrm{L}$ being injected. The mass spectrophotometer had its ionization energy adjusted to $70 \mathrm{eV}$ and the indentification of the individual components was based on its mass spectrum fragmentation, according to its NIST Mass 08 spectral library, retention indices and comparison with published data (Adams, 1995).

\subsection{Allelopathic Activity of the Essential Oils}

Initially, C. jamacaru subsp. jamacaru seeds were immersed in 5\% hypochlorite for 5 minutes, and washed in running water for the same time for complete sterilization. The essential oils obtained were first diluted in Dimethyl sulfoxide (DMSO) at a $1 \%$ DMSO percentage to avoid interference with germination, and were subsequently diluted to the $1000,500,250$ and $125 \mu \mathrm{g} / \mathrm{mL}$ concentrations for the realization of the allelopathic bioassays. The concentrations used in this study are based on the fact that the species present variations in the leaf drop rates, and that $M$. suaveolens is the one with the greatest contribution in leaf dry biomass in relation to the other aromatic species, with a rate of 3 sheets tonelas per hectare, and as its oil has a yield of $0.153 \%$ dry weight yield, will have a ratio of around $459 \mu \mathrm{g}$ of oil per $\mathrm{ml}$ of soil, whereas the leaves are in an engagement with depth of $1 \mathrm{~cm}$ from soil (Bezerra et al., 2017). 
Each treatment consisted of four replicates with 25 seeds each, totaling 100 seeds per treatment. The assays were assembled on Petri dishes, lined with two germitest paper sheets, moistened with $3 \mathrm{~mL}$ distilled water (Meiado, Rojas-Aréchiga, Siqueira-Filho, \& Leal, 2016). The plates were maintained in a Biochemical Oxygen Demand (B.O.D.) germination chamber, with a 12 hour light/dark photoperiod at a constant temperature of $30{ }^{\circ} \mathrm{C}$, as according to Meiado et al. (2010). Observations were performed every 24 hours for 7 days, where seeds were considered to be germinated when their radicles achieved at least $1 \mathrm{~mm}$ in length.

The osmolarity and $\mathrm{pH}$ were analyzed. The latter was calibrated and adjusted to neutral ranges, between 6.5 and 7.5 , when necessary with $0.1 \mathrm{~mol} / \mathrm{L} \mathrm{KOH}$ and $5 \% \mathrm{HCl}$ solutions, since in allelopathic assays it is important that $\mathrm{pH}$ ranges are not very acidic or alkaline as these may be harmful to seed germination (Periotto, Perez \& Lima, 2004). The osmolarity values were measured with a PZL-1000 Osmometer.

\subsection{Analyzed Variables}

\subsubsection{Germination Percentage (GP)}

The germination percentage (GP) - number of seeds that generate normal seedlings, with preserved essential structures, such as a radicular system (primary root), aerial part (hypocotyl), terminal buds and cotyledons were verified. The following formula was used:

$$
G P=N / N t \times 100
$$

Where, $\mathrm{N}$ refers to the number of germinated seeds and $\mathrm{Nt}$ refers to the total number of seeds sown.

\subsubsection{Germination Velocity Index (GVI)}

Maguire's (1962) formula was adopted to determine the GVI:

$$
G V I=E^{1} / N^{1}+E^{2} / N^{2}+\ldots+E^{n} / N^{n}
$$

Where, $E^{1}, E^{2}$ and $E^{n}$ are the number of normal seedlings emerged computed at the first, second and last counts, respectively; and $\mathrm{N}^{1}, \mathrm{~N}^{2}$ and $\mathrm{N}^{\mathrm{n}}$ are the number of days from sowing to the first, second and last count.

\subsubsection{Mean Germination Time (Tm)}

To evaluate the mean emergence time, the formula proposed by Edmond and Drapala (1958) was used:

$$
T m=E^{1} T^{1}+E^{2} T^{2}+\ldots+E^{n} T^{n} / E^{1}+E^{2}+\ldots+E^{n}
$$

Where, $\mathrm{Tm}$ is the average time required for the species to reach maximum germination; $\mathrm{E}^{1}, \mathrm{E}^{2}$ and $\mathrm{E}^{\mathrm{n}}$ corresponds to the number of seedlings emerged at times $\mathrm{T}^{1}, \mathrm{~T}^{2}$ and $\mathrm{T}^{\mathrm{n}}$.

\subsection{Statistical Analysis}

For the statistical analysis of the data, the mean ( \pm standard deviation) were used and analyzed using the GraphPadPrism 6 software with a two-way analysis of variance (two-way ANOVA), followed by Tukey's test ( $p$ $<0.05)$.

\section{Results}

\subsection{Phytochemical Analysis}

The $\mathrm{pH}$ value of the oils varied according to the plants. For the osmolarity, osmotic pressures were proportional to the concentrations, that is, the higher the concentration, the higher the osmotic pressure the oil presented. The M. suaveolens EO presented the highest osmotic pressure at the concentration of $1000 \mu \mathrm{g} / \mathrm{mL}$. Thus, it was evident that this oil presents a large number of dissolved solutes (Table 1). 
Table 1. Physicochemical parameters for the different concentrations of the Mesosphaerum suaveolens (L.) Kuntze (Lamiaceae), Lantana montevidensis (Spreng.) Briq. (Verbenaceae), Lantana camara L. (Verbenaceae) and Tarenaya spinosa (Jacq.) Raf. (Cleomaceae) essential oils

\begin{tabular}{lllll}
\hline Tested Species & Concentration $(\boldsymbol{\mu g} / \mathbf{m L})$ & $\mathbf{p H}$ measured & Adjusted $\mathbf{p H}$ & Osmolarity $(\mathbf{M P a})$ \\
\hline Mesosphaerum suaveolens & 125 & 9.61 & 6.89 & -0.027 \\
& 250 & 9.52 & 6.73 & -0.074 \\
& 500 & 9.25 & 7.18 & -0.154 \\
\hline Lantana montevidensis & 1000 & 4.68 & 6.87 & -0.404 \\
\hline Lantana camara & 125 & 6.01 & 6.65 & -0.02 \\
& 250 & 5.23 & 7.41 & -0.065 \\
& 500 & 5.52 & 6.61 & -0.152 \\
& 1000 & 4.87 & 7.25 & -0.304 \\
\hline Tarenaya spinosa & 125 & 4.68 & 6.76 & -0.015 \\
& 250 & 6.2 & 6.87 & -0.052 \\
& 500 & 5.93 & 6.74 & -0.124 \\
& 1000 & 5.43 & 6.74 & -0.268 \\
\hline & 125 & 4.56 & 6.54 & -0.024 \\
& 250 & 5.89 & 6.93 & -0.054 \\
& 500 & 9.54 & 6.71 & -0.131 \\
& 1000 & 4.91 & 6.74 & -0.281 \\
\hline
\end{tabular}

\subsection{Essential Oil Chemical Composition}

The results indicate that the oils from all the species are rich in mono- and sesquiterpenes. Moreover, the compositions were shown to be very heterogenous, with the M. suaveolens EO being the one with the highest number of constituents (44 constituents), followed by the L. camara (26 constituents), T. spinosa (23 constituents) and L. montevidensis (22 constituents) EOs (Table 2).

No major components, those with greater than $20 \%$ composition, were found. However, within the $M$. suaveolens EO secondary constituents, three occurred in greater quantity: $\beta$-Cariophilene (18.57\%), sabinene $(15.99 \%)$ and spatulenol $(11.09 \%)$, totalling $45.58 \%$ of the EO constitution. This oil, for being largely heterogenous, presented a total of 26 trace components (below 1\%), with (Z)- $\beta$-ocimene $(0.07 \%)$, $\alpha$-Cupene $(0.09 \%)$ and $\delta$-cadidene $(0.09 \%)$ being the constituents which presented the lowest constitution percentage (Table 2).

The L. montevidensis species presented only two major components: $\beta$-caryophyllene (34.96\%) and germacrene D (25.49\%), which together totalled $60.45 \%$ of the EO's chemical content. As for the secondary constituents, 11 chemical components were identified, however, bicyclogermacrene $(9.78 \%)$ and $\alpha$-copaene $(5.05 \%)$ were the ones with the highest prevalence. While the trace constituent (E)-caryophyllene $(0.08 \%)$ presented with the lowest percentage (Table 2).

In the L. camara essential oil, (E)-caryophyllene (24.28\%) was the chemical constituent identified as the major compound. While bicyclogermacrene (15.92\%), germacrene D (11.83\%) and Valencene $(8.37 \%)$ were the three secondary constituents with the highest percentage, making up $36.12 \%$ of the EO constitution. Regarding the trace components identified by chromatography, 10 compounds were totalled, with camphene $(0.09 \%)$ being the lowest percentage constituent (Table 2).

The $T$. spinosa EO was the only one which presented a diterpene $\left(\mathrm{C}_{20}\right)$, phytol $(27.19 \%)$, as its major component. As secondary constituents, chromatography identified $\alpha$-farnesen $(11.56 \%)$ and eugenol $(7.34 \%)$ with greatest predominance. In addition, a total of 8 trace components present in this oil, with methyl benzoate $(0.07 \%)$ and $\gamma$-cadinene (0.09) being identified at an oil concentration below $1 \%$ (Table 2). Some constituents, such as $\beta$-caryophyllene, allo-aromadendrene, germacrene $\mathrm{D}$, espatulenol and caryophyllene oxide, were present in all the oils. 
Table 2. Chemical composition of the Mesosphaerum suaveolens (L.) Kuntze, Lantana montevidensis (Spreng.) Briq., Lantana camara L. and Tarenaya spinosa (Jacq.) Raf. Essential oils

\begin{tabular}{|c|c|c|c|c|c|c|}
\hline \multirow{2}{*}{ Constituents } & \multirow{2}{*}{$\mathbf{R} \mathbf{I}^{\mathbf{a}}$} & \multirow{2}{*}{$\mathbf{R I}^{\mathbf{b}}$} & \multicolumn{4}{|c|}{ Chemical Composition } \\
\hline & & & M. suaveolens & L. montevidensis & L. camara & T. spinosa \\
\hline$\alpha$-Thujene & 989 & 931 & 1.09 & - & - & - \\
\hline$\alpha$-Pinene & 940 & 939 & 0.85 & - & 0.20 & 0.25 \\
\hline Sabinene & 976 & 976 & 15.94 & 1.09 & 6.05 & - \\
\hline$\beta$-Pinene & 980 & 980 & 2.11 & - & 0.51 & - \\
\hline Myrcene & 994 & 991 & 0.26 & - & 0.28 & 0.74 \\
\hline$\delta$-2-Carene & 999 & 1001 & 0.49 & - & - & - \\
\hline$\alpha$-Felandrene & 1006 & 1005 & 1.38 & - & - & 2.63 \\
\hline$\alpha$-Terpinene & 1019 & 1018 & 1.05 & - & 0.07 & - \\
\hline p-Cimene & 1030 & 1029 & 0.76 & - & 2.86 & 3.51 \\
\hline Limonene & 1031 & 1031 & 5.19 & - & - & - \\
\hline 1-8-Cineol & 1037 & 1033 & 3.04 & - & - & - \\
\hline (Z)- $\beta$-Ocimene & 1041 & 1040 & 0.07 & - & 0.73 & - \\
\hline (E)- $\beta$-Ocimene & 1055 & 1050 & 0.12 & - & 0.97 & - \\
\hline$\gamma$-Terpinene & 1060 & 1061 & 2.97 & - & 1.85 & - \\
\hline$t$-Sabinene hydrate & 1068 & 1068 & 0.61 & 0.56 & 0.15 & - \\
\hline Linalool & 1095 & 1098 & 0.43 & 3.40 & - & 1.59 \\
\hline Cis-p-Menth-2-en-1-ol & 1123 & 1121 & 0.28 & - & - & - \\
\hline t-Sabinol & 1139 & 1140 & 0.15 & - & - & - \\
\hline 4-Terpineol & 1178 & 1177 & 6.82 & - & - & - \\
\hline p-Cymen-8-ol & 1183 & 1183 & 0.23 & - & - & - \\
\hline$\alpha$-Terpineol & 1191 & 1189 & 0.94 & - & 1.10 & - \\
\hline$\delta$-Elemene & 1335 & 1338 & 1.17 & - & - & - \\
\hline$\alpha$-Cupene & 1377 & 1376 & 0.09 & 5.05 & 1.01 & - \\
\hline$\beta$-Elemene & 1390 & 1391 & 0.78 & 2.61 & 1.52 & - \\
\hline$\beta$-Cedrene & 1416 & 1417 & 0.14 & - & - & - \\
\hline$\beta$-Caryophyllene & 1421 & 1418 & 18.57 & 34.96 & 3.69 & 1.62 \\
\hline$\beta$-Gurjunene & 1433 & 1432 & 0.23 & - & - & - \\
\hline$\gamma$-Elemene & 1435 & 1433 & 1.44 & - & - & 0.61 \\
\hline Aromadendrene & 1439 & 1439 & 0.32 & - & - & - \\
\hline$\alpha$-humulene & 1453 & 1454 & 1.17 & 2.56 & 4.03 & - \\
\hline Allo-aromadendrene & 1461 & 1462 & 0.40 & 1.35 & 2.35 & - \\
\hline$\gamma$-Muurolene & 1477 & 1477 & 0.28 & - & - & - \\
\hline Germacrene D & 1481 & 1480 & 5.21 & 25.49 & 11.83 & 0.34 \\
\hline$\beta$-selinene & 1486 & 1485 & 0.89 & - & - & - \\
\hline Bicyclogermacrene & 1501 & 1488 & 7.52 & 9.78 & 15.92 & - \\
\hline$\gamma$-Cadinene & 1512 & 1513 & 0.36 & - & - & 0.09 \\
\hline$\delta$-Cadidene & 1525 & 1520 & 0.09 & 0.13 & - & - \\
\hline Germacrene B & 1559 & 1556 & 0.27 & - & - & - \\
\hline Spathulenol & 1576 & 1576 & 11.09 & 2.23 & 2.13 & 6.12 \\
\hline Caryophyllene Oxide & 1580 & 1581 & 3.18 & 3.94 & 2.78 & 9.07 \\
\hline Globulol & 1582 & 1583 & 0.62 & - & - & - \\
\hline Cubenol & 1641 & 1642 & 1.07 & - & - & - \\
\hline$\beta$-Eudesmol & 1649 & 1649 & 0.13 & - & - & - \\
\hline$\alpha$-Cadinol & 1656 & 1653 & 0.45 & - & - & - \\
\hline Camphene & 953 & 951 & - & 0.56 & - & - \\
\hline p-Cimene & 1026 & 1026 & - & 0.67 & - & - \\
\hline Terpinolene & 1088 & 1079 & - & 1.15 & 5.48 & - \\
\hline cis-Linalool Oxide & 1074 & 1074 & - & 0.53 & - & - \\
\hline
\end{tabular}




\begin{tabular}{lllllll}
\hline Camphor & 1143 & 1141 & - & 0.78 & - & - \\
Terpinen-4-ol & 1177 & 1174 & - & 0.17 & 0.23 & - \\
(E)-Caryophyllene & 1418 & 1423 & - & 0.08 & 24.28 & - \\
Valencene & 1491 & 1489 & - & 1.58 & 8.37 & - \\
a-Cadidene & 1538 & 1538 & - & 0.45 & 0.18 & - \\
Camphene & 953 & 951 & - & - & 0.09 & 1.09 \\
Methyl benzoate & 1091 & 1087 & - & - & - & 0.07 \\
Thymol & 1290 & 1287 & - & - & - & 0.95 \\
Eugenol & 1356 & 1329 & - & - & - & 7.34 \\
a-Humulene & 1452 & 1439 & - & - & - & 2.08 \\
a-Farnesene & 1503 & 1503 & - & - & - & 11.56 \\
Hexadecane & 1600 & 1601 & - & - & - & 3.85 \\
Eudesmol & 1615 & 1618 & - & - & - & 4.19 \\
Caryophyllene Acetate & 1700 & 1704 & - & - & - & 0.13 \\
N-Hexadecanoic acid & 1984 & 1985 & - & - & - & 3.56 \\
Phytol & 2065 & 2049 & - & - & - & 27.19 \\
Incensole & 2158 & 2172 & - & - & - & 5.73 \\
Total (\%) & & & $\mathbf{9 9 . 9 7}$ & $\mathbf{9 9 . 1 2}$ & $\mathbf{9 8 . 6 6}$ & $\mathbf{9 4 . 3 1}$ \\
\hline
\end{tabular}

Note. Relative proportion of essential oil constituents expressed as a percentage.

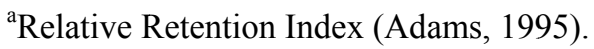

${ }^{b}$ Experimental Retention Index (based on the homologous $n$-alkane $\mathrm{C}_{7}-\mathrm{C}_{30}$ series).

\subsection{Germination Percentage}

All the analyzed oils displayed a significant negative allelopathic effect on the C. jamacaru subsp. jamacaru germination percentage. In addition, germination percentage is inversely proportional to the concentration of the oils (Figure 1).

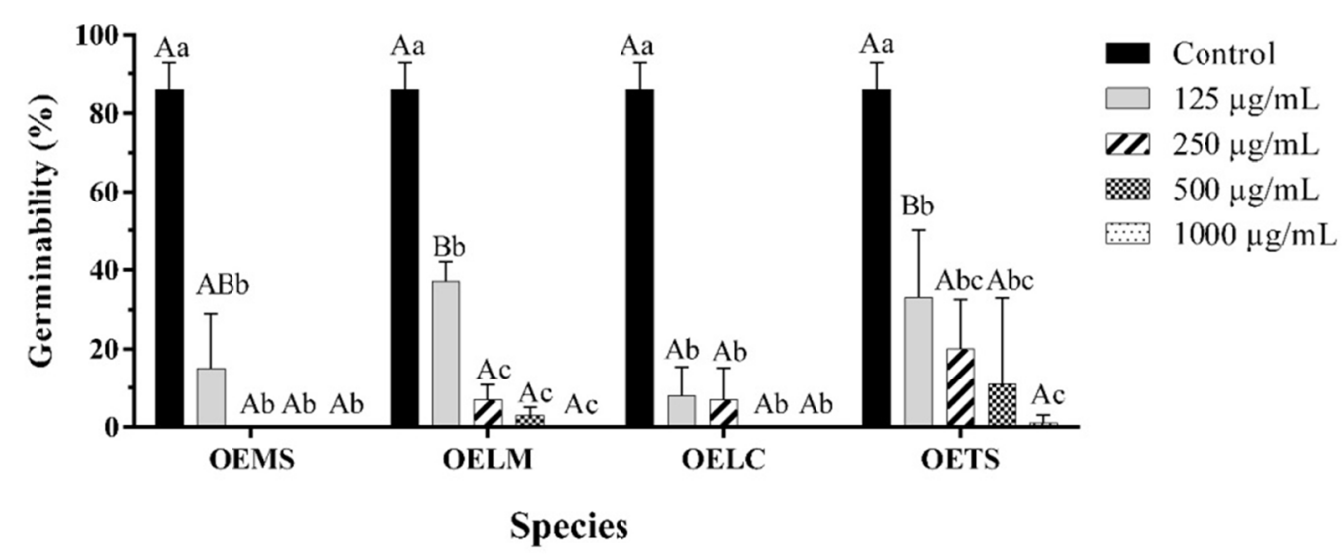

Figure 1. Germinability of Cereus jamacaru DC. subsp. jamacaru (Cactaceae) seeds against different concentrations $(\mu \mathrm{g} / \mathrm{mL})$ of the essential oils from (OEMS) Mesosphaerum suaveolens (L.) Kuntze (Lamiaceae), (OELM) Lantana montevidensis (Spreng.) Briq. (Verbenaceae), (OELC) Lantana camara L. (Verbenaceae) and

(OETS) Tarenaya spinosa (Jacq.) Raf. (Cleomaceae). Capital letters compare the same essential oil concentration between different species. Lowercase letters compare the different concentrations from the same species

The M. suaveolens EO had a high allelopathic effect as it completely inhibited seed germination at 250,500 and $1000 \mu \mathrm{g} / \mathrm{mL}$ concentrations over the 7 days, whereas a low germination percentage (with only $20 \pm 9.79 \%$ ) was observed at the $125 \mu \mathrm{g} / \mathrm{mL}$ concentration. For the control group, a total of $86 \pm 6.92 \%$ of seeds germinated (Figure $1)$. 
The L. montevidensis EO also presented negative allelopathic activity against the $C$. jamacaru subsp. jamacaru seeds. The $1000 \mu \mathrm{g} / \mathrm{mL}$ concentration completely inhibited seed germination during 7 days. In addition, the higher the EO's concentration, the lower the percentage of seeds were germinated. In the remaining concentrations, germination was observed, however, at low percentages such as in the group with the lowest concentration $(125 \mu \mathrm{g} / \mathrm{mL})$, where only $37 \pm 5.03 \%$ of seeds were germinated, less than half the germination percentage of the control group (Figure 1).

As for the L. camara $\mathrm{EO}$, at concentrations $\geq 500 \mu \mathrm{g} / \mathrm{mL}$, this inhibited C. jamacaru subsp. jamacaru seed germination, since no germination was observed for 7 days. At concentrations $\leq 250 \mu \mathrm{g} / \mathrm{mL}$, some seeds germinated, however the percentage was low, such as at $125 \mu \mathrm{g} / \mathrm{mL}$ of the EO where only $8.0 \pm 7.3 \%$ of the seeds germinated (Figure 1).

The T. spinosa EO showed the lowest negative allelopathic activity when compared to the other oils, since some seeds germinated at the highest concentration $(1000 \mu \mathrm{g} / \mathrm{mL})$, despite obtaining low germination percentages. Moreover, in the $125 \mu \mathrm{g} / \mathrm{mL}$ treatment, germination was observed in $33 \pm 17 \%$ of seeds, which, although the seeds were shown to be more tolerant to this oil, the EO still promoted a high negative allelopathic action (Figure 1). It is noteworthy that the different oil concentrations inhibited germination in different ways, as the $L$. camara EO had a more negative allelopathic effect than the L. montevidensis and T. spinosa EOs at the 125 $\mu \mathrm{g} / \mathrm{mL}$ concentration (Figure 1; Table 3 ).

Table 3. Two-way ANOVA results for the germination percentage (\%), germination velocity index and mean germination time of Cereus jamacaru DC. subsp. jamacaru (Cactaceae) seeds against different concentrations $(\mu \mathrm{g} / \mathrm{mL})$ of the Mesosphaerum suaveolens (L.) Kuntze (Lamiaceae), Lantana montevidensis (Spreng.) Briq. (Verbenaceae), Lantana camara L. (Verbenaceae) and Tarenaya spinosa (Jacq.) Raf. (Cleomaceae) essential oils

\begin{tabular}{llll}
\hline & $\mathrm{F}$ & $\mathrm{gl}$ & $\mathrm{p}$ \\
\hline Germination Percentage (\%) & & & \\
Species & 6.5821 & 3.60 & 0.0009 \\
Concentration & 271.5362 & 4.60 & $<0.0001$ \\
Species $\times$ Concentration & 2.2629 & 12.60 & 0.0191 \\
\hline Germination Velocity Index & & & \\
Species & 3.6347 & 3.60 & 0.0175 \\
Concentration & 51.014 & 4.60 & $<0.0001$ \\
Species $\times$ Concentration & 0.978 & 12.60 & 0.5198 \\
- Mean Germination Time (days) & & & $<0.0001$ \\
Species & 113.512 & 3.60 & $<0.0001$ \\
Concentration & 351.4481 & 4.60 & $<0.0001$ \\
Species x Concentration & 59.1192 & 12.60 & \\
\hline
\end{tabular}

\subsection{Germination Velocity Index (GVI)}

The essential oils from the four plants analyzed affected the germination speed of $C$. jamacaru subsp. jamacaru seeds in a dose-dependent manner, such that the higher the EO concentration, the slower the germination speed.

The $L$. camara EO was the one which most affected the GVI of $C$. jamacaru subsp. jamacaru seeds at the lowest tested concentration of $125 \mu \mathrm{g} / \mathrm{mL}$ which was $0.38 \pm 0.36$. Similarly, the M. suaveolens and L. montevidensis oils negatively affected the GVI in all the concentrations. For T. spinosa, the EO from this species significantly affected the GVI only at concentrations $\geq 500 \mu \mathrm{g} / \mathrm{mL}$ (Table 4). 
Table 4. Germination Velocity Index (GVI) of Cereus jamacaru DC. subsp. jamacaru seeds against essential oils from Mesosphaerum suaveolens (L.) Kuntze, Lantana montevidensis (Spreng.) Briq., Lantana camara L. and Tarenaya spinosa (Jacq.) Raf

\begin{tabular}{lllll}
\hline Concentration $\boldsymbol{\mu g} / \mathbf{m L}$ & OEMS & OELM & OELC & OETS \\
\hline 125 & $0.71 \pm 0.60 \mathrm{~b}$ & $1.34 \pm 0.76 \mathrm{~b}$ & $0.38 \pm 0.36 \mathrm{~b}$ & $1.69 \pm 0.77 \mathrm{ab}$ \\
250 & $0 \pm 0 \mathrm{~b}$ & $0.31 \pm 0.24 \mathrm{bc}$ & $0.42 \pm 0.49 \mathrm{~b}$ & $1.14 \pm 0.72 \mathrm{ab}$ \\
500 & $0 \pm 0 \mathrm{~b}$ & $0.11 \pm 0.07 \mathrm{c}$ & $0 \pm 0 \mathrm{~b}$ & $0.62 \pm 1.25 \mathrm{~b}$ \\
1000 & $0 \pm 0 \mathrm{~b}$ & $0 \pm 0 \mathrm{c}$ & $0 \pm 0 \mathrm{~b}$ & $0.03 \pm 0.07 \mathrm{~b}$ \\
Control $\left(\mathrm{H}_{2} \mathrm{O}\right)$ & $2.64 \pm 0.87 \mathrm{a}$ & $2.64 \pm 0.87 \mathrm{a}$ & $2.64 \pm 0.87 \mathrm{a}$ & $2.64 \pm 0.87 \mathrm{a}$ \\
\hline
\end{tabular}

Note. Means followed by the same letter column do not differ from each other at $5 \%$ probability by Tukey's test. OEMS: Mesosphaerum suaveolens (L.) Kuntze essential oil; OELM: Lantana montevidensis (Spreng.) Briq. essential oil; OELC: Lantana camara L. essential oil; OETS: Tarenaya spinosa (Jacq.) Raf. essential oil.

\subsection{Mean Germination Time (Tm)}

Although the oils affected the germination percentage and the germination velocity index of $C$. jamacaru subsp. jamacaru seeds, those which germinated were not significantly affected with respect to the mean germination time. Even though germination was inhibited at concentrations $\geq 250 \mu \mathrm{g} / \mathrm{mL}$, the M. suaveolens EO at the 125 $\mu \mathrm{g} / \mathrm{mL}$ concentration had a Tm of $5.16 \pm 0.81$, not differing from the control group (Tm: 4.97 \pm 0.54 ). The same occurred with the other essential oils (Figure 2).

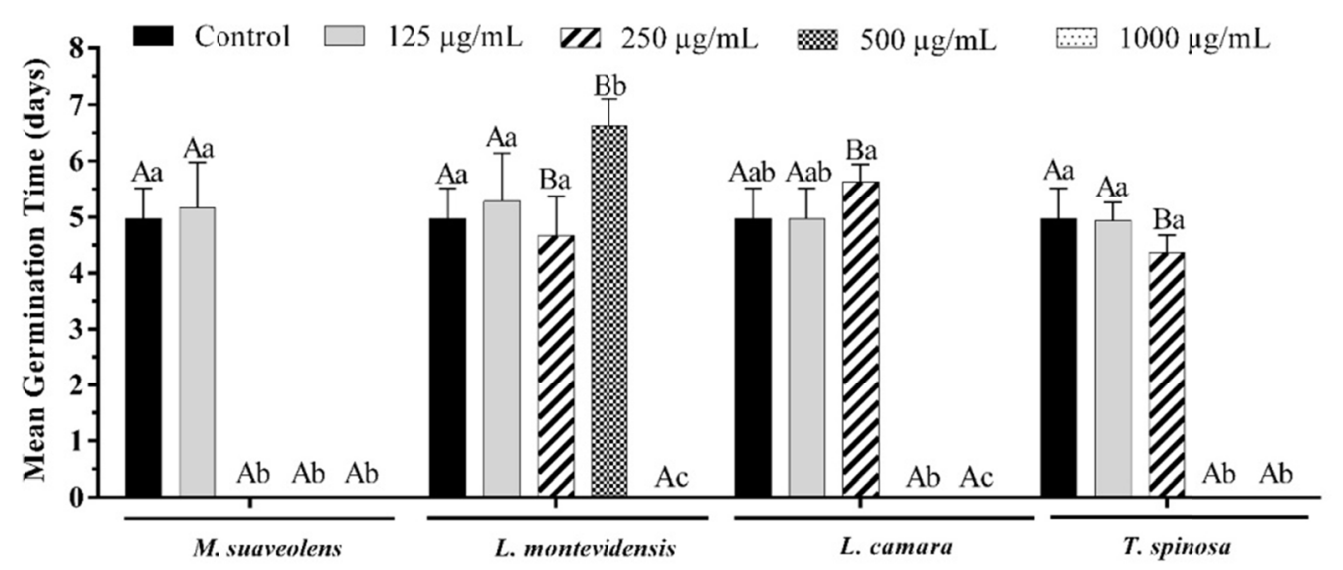

Figure 2. Mean germination time of C. jamacaru DC. subsp. jamacaru seeds subjected to the OEMS, OELM, OELC and OETS. Mean ( \pm standard deviation). Capital letters compare the same essential oil concentration between different species. Lowercase letters compare different concentrations from the same species

\section{Discussion}

In this study, C. jamacaru DC. subsp. jamacaru seeds obtained an average germination time of 4.9 days, which may be justified by the distribution of this species, native to the semi-arid region of Brazil, a region characterized by sporadic rains in which the available water time in superficial soils is reduced and the seeds need to germinate in a few days in order to make the most of the available water for their metabolic processes (Rito, Rocha, Leal, $\&$ Meiado, 2009). This average germination time may represent a pattern for some Cactaceae species such as Pilosocereus gounellei (F.A.C.Weber) Byles \& G.D. Rowley. (xique-xique) (Abud et al., 2012), Pilosocereus arrabidae (Lem.) Byles \& Rowley (Facheiro-da-praia) (Martins et al. 2012) and Discocactus zehntneri Britton \& Rose subsp. Zehntneri (Meiado et al., 2016). Whereas, other cacti species have a higher Tm, as cited in the study by Meiado et al. (2016), for Facheiroa squamosa (Gürke) P.J.Braun \& E. Esteves Pereira (Facheiro-preto), Harrisia adscendens (Gürke) Britton and Rose (Rabo-de-raposa) and Melocactus ernestii Vaupel subsp. ernestii. There are few cacti which require more than ten days to germinate under suitable conditions such as Pilosocereus pentaedrophorus (J.F.Cels) Byles \& G.D. Rowley subsp. pentaedrophorus (mandacaru-de-veado), 
from the Atlantic Forest, an ecosystem which is subjected to less water stress, compared with the Cerrado and the Caatinga (Meiado et al., 2016).

For allelopathic tests, osmolarity levels should be very close to $0 \mathrm{MPa}$ since solute levels negatively and significantly interfere with seed germinability (Góis, Torres, \& Pereira, 2008). High osmolarity levels exert a harmful osmotic pressure between the solution and the seeds, consequently, water does not penetrate the seeds and in this way it inhibits or slows down germination (Ortiz, Gomes, Urbano, \& Strapasson, 2014). However, in the evolutionary scale, cacti developed strategies to survive in arid environments where a high rate of soil water evaporation and low drainage predominate, resulting in the accumulation of solutes such as salts, thus, seeds from these plants are generally tolerant to salt stress (Góis et al., 2008).

C. jamacaru subsp. jamacaru tolerate high saline stress, that is, they are halotolerant which can be observed in a study by Meiado et al. (2010) who found a percentage of germinated seeds, not differing from the control group, which were subjected to an osmotic potential of up to $-0.6 \mathrm{MPa}$. Thus, with respect to allelopathic activities, all the essential oils presented a negative allelopathic activity against $C$. jamacaru subsp. jamacaru seeds. since the results are not attributable to the osmotic pressures exerted by the oils' solutes, given that the highest osmotic pressure exerted was $0.404 \mathrm{MPa}$ from the M. suaveolens $\mathrm{EO}$ at the $1000 \mu \mathrm{g} / \mathrm{mL}$ concentration.

The oils' allelopathic effects may be due to the action of the major constituents or by a synergism from all or some of the EO's chemical constituents (Simões, Schenkel, Mello, Mentz, \& Petrovick, 2017). The EO's allelochemical mechanisms of action are varied and may have effects similar to those from flavonoids, which may act as ion channel regulators involved in oxidative phosphorylation or may close these channels, thus preventing ions from flowing through the cytoplasmic membrane. In addition, when these constituents are in high concentrations in the intracellular medium, they may hyperpolarize such membranes, altering ATP pump functioning and, consequently, preventing germination (Martino et al. 2012).

For M. suavoelens, the allelopathic action may be attributed to a synergistic action from the $\beta$-Caryophyllene (18.57\%), sabinene (15.99\%) and spatulenol (11.09\%) secondary constituents. In the study by Miranda, Cardoso, Carvalho, Figueiredo and Andrade (2015), $\beta$-caryophyllene constituted $13.2 \%$ of the Hedychium coronarium J. Koenig (lírio-do-brejo) EO and showed relatively low negative allelopathic effects on Lactuca sativa L. (lettuce) seeds., which are sensitive to allelochemicals. However, this chemical component needs other components to act on seed germination. Whereas, sabinene is a cyclic hydrocarbon monoterpene which, according to Sikkema, Bont, and Poolman (1995), causes alterations in cell membrane structure and function, preventing growth and cellular activities, therefore, the action observed in this study may be related to a synergistic action of the aforementioned constituents.

As for the M. suaveolens EO chemical composition, its constitution is variable according to the plant origin, which is evidenced in the study by Benelli, Flamini, Canale, Cioni, and Conti (2012), where the EO of individuals from the same species, collected in Italy, showed variations in constitution percentage and in main constituents, with emphasis on sabinene (34.0\%), $\beta$-caryophyllene (11.2\%) and terpinolene (10.7\%), where in the present study the latter constituent is not present in the EO obtained. In the study by Rodrigues et al. (2012) the main constituents obtained from leaves in the Minas Gerais (BR) state were trans-caryophyllene (18.15\%), beta-elemene (7.26\%) and caryophyllene oxide (6.97\%). Despite EO being obtained from specimens collected in Brazil, when compared to the EO in this study, the observed composition varied considerably. These differences may be justified by the different cultivation forms, harvesting periods, climatic stress and, especially, the geographic origin of the plant (Noudjou et al., 2007).

The L. montevidensis essential oil also negatively affected the germination of $C$. jamacaru subsp. jamacaru seeds. This fact can be attributed to the two major sesquiterpenes present, $\beta$-caryophyllene and germacrene D. In the study by Ayeb et al. (2016), the allelochemical action of the Tipuana tipu (Benth.) Kuntze essential oil against $L$. sativa seeds was verified to be due to these two sesquiterpenes.

The L. camara allelopathic effect was also recorded by Kong, Wang, Zhang, Zhang and Hu (2006) which, according to the authors, this effect was due to pentacyclic triterpenoid $\left(\mathrm{C}_{30}\right)$ compounds, Lanthanum $\mathrm{A}$ and Lanthanum B. However, in our study, the allelopathic action observed is attributed to volatile terpenes, since the mentioned triterpenoids are not present in our essential oils.

The seed germination inhibitory effect promoted by the $T$. spinosa essential oil over C. jamacaru subsp. jamacaru seeds is justified by its major constituent phytol, which is a cytotoxic and genotoxic diterpene responsible for inducing apoptosis in plant cells, as well as nuclear anomalies and pro-oxidative effects (Islam et al., 2017). This constituent is also present in other species from the Cleomaceae family, such as in Cleome serrata (Mcneil, Porter, \& Williams, 2012). With this, the sowing of C. jamacaru subsp. jamacaru seeds should 
not be performed near these two species, as well as other species that present the diterpene phytol as an oil constituent.

In the northeastern semi-arid region, plants are subjected to several abiotic stresses, such as high temperatures, high radiation rate and water stress during their growth and development. Therefore, there is an increase in the production and release of secondary metabolites, especially volatile terpenes (Oliveira Junior et al., 2011). Thus, allelochemical release in the medium will be greater at times of prolonged drought and high temperatures for $L$. montevidensis, L. camara and T. spinosa, since these species present leaves during the dry season, while $M$. suaveolens is not established in this period as it is an annual species which grows and reproduces during the rainy season (Bezerra et al., 2017).

However, although the volatile terpenes analyzed here may be detrimental to the C. jamacaru subsp. jamacaru ecological succession, some EO's may be beneficial to seeds from this plant aiding the perpetuation of the species (Hillen et al., 2012), such as the Pimpinella anisum L. and Cymbopogon winterianus Jowitt EOs. These oils can, in addition to controlling the pathogens present in seeds, they can increase their germinability, that is, they present positive allelopathy (Mata, Araujo, Nascimento, Souza, \& Viana, 2009). Thus, a better understanding of the species occurring in the Caatinga and those which produce allelochemicals will aid the development of $C$. jamacaru subsp. jamacaru conservation strategies, in addition to limiting the spread of weeds, thus preserving the native plants.

\section{Conclusion}

In reforestation programs, C. jamacaru subsp. jamacaru seeds should not be sown near M. suaveolens, $L$. montevidensis, L. camara and $T$. spinosa since these species release essential oils in the environment with potential negative allelopathic activity, affecting C. jamacaru subsp. jamacaru seeds. Such allelochemicals may impair the ecological succession of the cactus under study.

\section{Acknowledgements}

The Cearense Foundation for Scientific and Technological Development Support-FUNCAP for financial support.

\section{References}

Abud, H. F., Gonçalves, N. R., Pereira, M. D. S., Pereira, D. D. S., Reis, R. D. G. E., \& Bezerra, A. M. E. (2012). Germination and morphological characterization of the fruits, seeds, and seedlings of Pilosocereus gounellei. Brazilian Journal of Botany, 35(1), 11-16. https://doi.org/10.1590/S1806-99592012000100003

Adams, R. P. (1995). Identification of essential oil components by Gas chromatography/mass spectroscopy. Illinois, USA: Allured Publishing Corporation.

Ayeb, X. E., Sakka-Rouis, L., Bergaoui, A., Flamini, G., Jannet, H. B., \& Harzallah-Skhiri, F. (2016). Chemical composition and allelopathic potential of essential oils from Tipuana tipu (Benth.) Kuntze cultivated in Tunisia. Chemistry biodiversity, 13(3), 309-318. https://doi.org/10.1002/cbdv.201500083

Benelli, G., Flamini, G., Canale, A., Cioni, P. L., \& Conti, B. (2012). Toxicity of some essential oil formulations against the Mediterranean fruit fly Ceratitis capitata (Wiedemann) (Diptera Tephritidae). Crop Protection, 42(12), 223-229. https://doi.org/10.1016/j.cropro.2012.05.024

Bezerra, J. W. A., Costa, A. R., Silva, M. A. P., Rocha, M. I., Boligon, A. A., da Rocha, J. B. T., ... Kamdem, J. P. (2017). Chemical composition and toxicological evaluation of Hyptis suaveolens (L.) Poiteau (Lamiaceae) in Drosophila melanogaster and Artemia salina. South African Journal of Botany, 113(11), 437-442. https://doi.org/10.1016/j.sajb.2017.10.003

Cavalcante, A., Teles, M., \& Machado, M. (2013). Cactos do semiárido do Brasil: Guia ilustrado. Campina Grande, PB: INSA.

Edmond, J. B., \& Drapala, W. J. (1958). The effects of temperature, sand and soil, and acetone on germination of okra seed. Proceedings of the American Society for Horticultural Science, 71(1), 428-434.

Gachon, C. M., Langlois-Meurinne, M., \& Saindrenan, P. (2005). Plant secondary metabolism glycosyltransferases: The emerging functional analysis. Trends in plant science, 10(11), 542-549. https://doi.org/10.1016/j.tplants.2005.09.007

Góis, V. A., Torres, S. B., \& Pereira, R. A. (2008). Germinação de sementes de maxixe submetidas a estresse salino. Revista Caatinga, 21(4), 64-67. 
Gomes, V. G. N., Meiado, M. V., Quirino, Z. G. M., \& Machado, I. C. (2016). Seed removal by lizards and effect of gut passage on germination in a columnar cactus of the Caatinga, a tropical dry forest in Brazil. Journal of Arid Environments, 135(12), 85-89. https://doi.org/10.1016/j.jaridenv.2016.08.013

Gomes, V. G. N., Quirino, Z. G. M., \& Araujo, H. F. P. (2014). Frugivory and seed dispersal by birds in Cereus jamacaru DC. ssp. jamacaru (Cactaceae) in the Caatinga of Northeastern Brazil. Brazilian Journal of Biology, 74(1), 32-40. https://doi.org/10.1590/1519-6984.15312

Hillen, T., Schwan-Estrada, K. R. F., Mesquini, R. M., Cruz, M. E. S., Stangarlin, J. R., \& Nozaki, M. (2012). Atividade antimicrobiana de óleos essenciais no controle de alguns fitopatógenos fungicos in vitro e no tratamento de sementes. Revista Brasileira de Plantas Medicinais, 14(3), 439-445. https://doi.org/10.1590/ S1516-05722012000300003

Islam, M. T., Streck, L., Alencar, M. V. O. B., Silva, S. W. C., Machado, K. C., Machado, K. C., ... Melo-Cavalcante, A. A. C. (2017). Evaluation of toxic, cytotoxic and genotoxic effects of phytol and its nanoemulsion. Chemosphere, 177(6), 93-101. https://doi.org/10.1016/j.chemosphere.2017.02.145

Judd, W. S., Campbell, C. S., Kellogg, E. A., Stevens, P. F., \& Donoghue, M. J. (2009). Sistemática vegetal: Um enfoque filogenético (3rd ed.). Porto Alegre, RS: Artmed.

Kong, C. H. Wang, P., Zhang, C. X., Zhang, M. X., \& Hu, F. (2006). Herbicidal potential of allelochemicals from Lantana camara against Eichhornia crassipes and the alga Microcystis aeruginosa. Weed Research, 46(4), 290-295. https://doi.org/10.1111/j.1365-3180.2006.00509.x

Li, Z. H., Wang, Q., Ruan, X., Pan, C. D., \& Jiang, D. A. (2010). Phenolics and plant allelopathy. Molecules, 15(12), 8933-8952. https://doi.org/10.3390/molecules15128933

Maguire, J. D. (1962). Speed of germination-aid in selection and evaluation for seedling emergence and vigor. Crop Science, 2(2), 176-177. https://doi.org/10.2135/cropsci1962.0011183X000200020033x

Martino, L., Mencherini, T., Mancini, E., Aquino, R. P., Almeida, L. F. R., \& Feo, V. (2012). In vitro phytotoxicity and antioxidant activity of selected flavonoids. International Journal of Molecular Sciences, 13(5), 5406-5419. https://doi.org/10.3390/ijms13055406

Martins, L. S. T., Mencherini, T., Mancini, E., Aquino, R. P., Almeida, L. F. R., \& Feo, V. (2012). Seed germination of Pilosocereus arrabidae (Cactaceae) from a semiarid region of south-east Brazil. Plant Species Biology, 27(3), 191-200. https://doi.org/10.1111/j.1442-1984.2011.00360.x

Mata, M. F., Araujo, E., Nascimento, L. C., Souza, A. E. F., \& Viana, S. (2009). Incidência e controle alternativo de patógenos em sementes de mandacaru (Cereus jamacaru DC, Cactaceae). Revista brasileira de Biociências, 7(4), 327-334.

Matos, F. J. A. (2009). Introdução a fitoquímica experimental (3rd ed.). Fortaleza, CE: UFC.

Mcneil, M. J., Porter, R. B., \& Williams, L. A. (2012). Chemical composition and biological activity of the essential oil from Jamaican Cleome serrata. Natural Product Communications, 7(9), 1231-1232.

Meiado, M. V., Albuquerque, L. S. C., Rocha, E. A., Rojas-Aréchiga, M., \& Leal, I. R. (2010). Seed germination responses of Cereus jamacaru DC. ssp. jamacaru (Cactaceae) to environmental factors. Plant Species Biology, 25(2), 120-128. https://doi.org/10.1111/j.1442-1984.2010.00274.x

Meiado, M. V., Rojas-Aréchiga, M., de Siqueira-Filho, J. A., \& Leal, I. R. (2016). Effects of light and temperature on seed germination of cacti of Brazilian ecosystems. Plant Species Biology, 31(2), 87-97. https://doi.org/10.1111/1442-1984.12087

Menezes, M. O. T., Taylor, N. P., \& Loiola, M. I. B. (2014). Flora do Ceará, Brasil: Cactaceae. Rodriguésia-Instituto de Pesquisas Jardim Botânico do Rio de Janeiro, 64(4), 757-774.

Miranda, C. A. S. F., Cardoso, M. D. G., Carvalho, M. L. M., Figueiredo, A. C. S., \& Andrade, J. D. (2015). Chemical characterisation and allelopathic potential of essential oils from leaves and rhizomes of white ginger. Revista Ciência Agronômica, 46(3), 555-562. https://doi.org/10.5935/1806-6690.20150038

Noudjou, F., Kouninki, H., Ngamo, L. S., Maponmestsem, P. M., Ngassoum, M., Hance, T., ... Lognay, G. C. (2007). Effect of site location and collecting period on the chemical composition of Hyptis spicigera Lam. an insecticidal essential oil from North-Cameroon. Journal of Essential Oil Research, 19(6), 597-601. https://doi.org/10.1080/10412905.2007.9699340 
Oliveira Junior, R. S., Constantin, J. \& Inoue, M. H. (2011). Biologia e manejo de plantas daninhas. Curitiba, PR: Omnipax.

Ortiz, T. A., Gomes, G. R., Urbano, M. R., \& Strapasson, E. (2014). Water and salt stress in germinating seeds of pitaya genotypes (Hylocereus spp.). African Journal of Agricultural Research, 9(50), 3610-3619. https://doi.org/10.5897/AJAR2014.9114

Periotto, F., Perez, S. C., \& Lima, M. I. (2004). Efeito alelopático de Andira humilis Mart. ex Benthna germinação e no crescimento de Lactuca sativa L. e Raphanus sativus L. Acta Botânica Brasilica, 18(3), 425-430. https://doi.org/10.1590/S0102-33062004000300003

Rito, K. F., Rocha, E. A., Leal, I. R., \& Meiado, M. V. (2009). As sementes de mandacaru têm memória hídrica. Boletín de La Sociedad Latino americana y del Caribe de Cactáceas y otras Suculentas, 6(1), 26-31.

Sharma, A., Batish, D. R., Singh, H. P., Jaryan, V., \& Kohli, R. K. (1995). The impact of invasive Hyptis suaveolens on the floristic composition of the periurban ecosystems of Chandigarh, northwestern India. Flora, 233(s/n), 156-162. https://doi.org/10.1016/j.flora.2017.04.008

Sikkema, J., Bont, J. A., \& Poolman, B. (1995). Mechanisms of membrane toxicity of hydrocarbons. Microbiological Reviews, 59(2), 201-222.

Simões, C. M. O., Schenkel, E. P., Mello, J. C. P., Mentz, L. A. \& Petrovick, P. R. (2017). Farmacognosia: Do Produto Natural ao Medicamento (2nd ed.). Porto Alegre, RS: Artmed.

\section{Copyrights}

Copyright for this article is retained by the author(s), with first publication rights granted to the journal.

This is an open-access article distributed under the terms and conditions of the Creative Commons Attribution license (http://creativecommons.org/licenses/by/4.0/). 